DOI: https://doi.org/10.47405/mjssh.v6i9.1053

\begin{tabular}{|c|c|}
\hline & Malaysian Journal of Social Sciences and Humanities (MJSSH) \\
\hline Malaysian Journal of & Volume 6, Issue 9, September 2021 \\
\hline 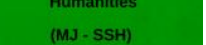 & e-ISSN : 2504-8562 \\
\hline & $\begin{array}{l}\text { Journal home page: } \\
\text { www.msocialsciences.com }\end{array}$ \\
\hline
\end{tabular}

\title{
Nilai Jaringan Sosial dan Model Kelestarian Perniagaan Perusahaan Kecil dan Sederhana (PKS) Melayu
}

\author{
Mohd Hadri Mohd Rifin', Novel Lyndon', Azlina Abdullah' \\ ${ }^{1}$ Centre for Research in Development, Social and Environment, \\ Faculty of Social Science and Humanities, Universiti Kebangsaan Malaysia (UKM) \\ Correspondence: Mohd Hadri Mohd Rifin (hadririfin@gmail.com)
}

\begin{abstract}
Abstrak
Hubungan jaringan sosial merupakan satu strategi perniagaan yang tersulamnya proses sosial melalui hubungan interaksi dalam aktiviti perniagaan. Justeru, isu utama kajian ini ialah sejauh mana hubungan jaringan sosial menghasilkan nilai jaringan yang membantu kelangsungan hidup dan daya saing perusahaan kecil dan sederhana milik orang Melayu. Kajian ini bertujuan mengenal pasti nilai jaringan sosial dalam membantu kelangsungan hidup dan daya saing perusahaan kecil dan sederhana milik orang Melayu melalui aktiviti pertukaran nilai jaringan bersama aktor jaringan sosial yang membentuk sebuah model kelestarian perniagaan. Kajian ini dijalankan menggunakan pendekatan kualitatif melibatkan temu bual mendalam dengan 20 orang informan yang merupakan usahawan kecil dan sederhana Melayu yang menjalankan perniagaan di Kuala Terengganu. Pemilihan informan kajian menggunakan kaedah pensampelan bertujuan. Ciri-ciri utama pemilihan informan ialah usahawan kecil dan sederhana yang mempunyai jumlah jualan tahunan melebihi RM300 ribu atau sekurang-kurangnya memiliki lima orang pekerja. Penganalisisan data kualitatif adalah secara bertema menggunakan perisian ATLAS.ti. Hasil kajian mendapati hubungan jaringan sosial menghasilkan nilai material dan nilai bukan material kepada usahawan Melayu. Aktiviti pertukaran nilai antara aktor jaringan sosial melibatkan perkongsian maklumat, tunjuk ajar, bantuan, perkhidmatan sokongan perniagaan, nasihat dan menyelesaikan masalah perniagaan. Impak dari pertukaran nilai jaringan sosial menghasilkan pelbagai manfaat kepada usahawan bermula dari proses penghasilan produk dan perkhidmatan yang berkualiti, strategi pemasaran, menepati kehendak pelanggan, kelangsungan perniagaan dan mampu bersaing dalam pasaran yang semakin mencabar. Kesimpulannya, membina hubungan bersama aktor jaringan sosial merupakan strategi perniagaan dan merupakan alat bagi usahawan Melayu untuk memiliki manfaat dalam perniagaan melalui peranan setiap aktor jaringan yang pelbagai, menghasilkan nilai jaringan yang berbeza, saling melengkapi dan saling diperlukan dalam membina sebuah perniagaan lestari yang bermatlamatkan nilai ekonomi, sosial dan persekitaran. Implikasi kajian menunjukkan bahawa usahawan Melayu perlu membina hubungan jaringan sosial di peringkat mikro dan makro termasuk institusi sosial.
\end{abstract}

Kata kunci: usahawan Melayu, jaringan sosial, perusahaan kecil dan sederhana, model kelestarian perniagaan

\section{Value of Social Networks Relation and Business Model Sustainability on Malay Small Medium Enterprises (SMEs)}

\section{Abstract}


Social networking relationship is a business strategy that is an embedded social process through interaction in business activities. Thus, the main issue of this study is the extent to which social networking relationships help produce the network values that ensure the viability and competitiveness of small and medium enterprises (SMEs) owned by the Malays. This study aims to identify the social networks in helping the survival and competitiveness of small and medium enterprises (SMEs) owned by Malays through network values exchange activities with the network of actors that make up a network model of business sustainability. This study used a qualitative approach involves in-depth interviews with 20 respondents representing small and mediumMalay entrepreneurs conducting businesses in Kuala Terengganu. Respondents were selected using purposive sampling method. The main characteristics of the selection of respondents are small and medium entrepreneurs who have annual sales in excess of MYR 300,000 or have at least five employees. Qualitative data analysis was done using thematic by the means of ATLAS.ti software. The study found that social networking relationships produce the tangible values and intangible values to Malay entrepreneurs. Value exchange activities between social network actors involve information sharing, mentoring, assistance, business support services, advice and business problem solving. The impact of the exchange of social networking values yields various benefits to entrepreneurs ranging from the process of producing quality products and services, marketing strategies, meeting customer needs, business continuity and being able to compete in an increasingly challenging market. In conclusion, building a relationship with the actor of social network is a business strategy and a tool for Malay entrepreneurs to benefit in business through the various role of each actor network, resulting in the various network values which complement each other and mutually necessary in building a sustainable business with the aim of economic, social and environmental values. The study showed that Malay entrepreneurs need to build a social network in the micro and macro levels, including social institutions.

Keywords: Malay entrepreneurs, social networks, small and mediumenterprise (SME), business sustainability model

\section{Pengenalan}

Matlamat model kelestarian perniagaan adalah mengoptimumkan nilai dan manfaat dari aspek ekonomi, sosial dan persekitaran dengan mengekalkan produktiviti dan keuntungan dalam perniagaan (Geissdoerfer et al., 2020; Schaltegger, Hansen \& Lüdeke-freund, 2016; Syllick \& Hockerts, 2002). Model kelestarian perniagaan merupakan satu set hubungan interaksi bersama pihak berkepentingan dalam membina, menerima, mencapai dan melakukan aktiviti pertukaran nilai dengan pelbagai pihak berkepentingan (Boons \& Lüdeke-Freund, 2013; Geissdoerfer, Vladimirova \& Evans, 2018). Clarkson (1995) mengklasifikasikan pihak berkepentingan kepada dua kategori iaitu primer yang merupakan individu utama dalam pengoperasian organisasi perniagaan seperti pekerja, pembekal, pelanggan dan pelabur; kategori kedua adalah sekunder yang merupakan individu atau institusi yang dapat mempengaruhi dan memberikan sokongan kepada organisasi perniagaan seperti agensi kerajaan, universiti, komuniti dan pertubuhan bukan kerajaan. Ini menjelaskan bahawa sesebuah organisasi perniagaan memerlukan penglibatan daripada pelbagai pihak untuk kelangsungan perniagaan. Sebuah model perniagaan tidak hanya terbatas pada persekitaran dalaman sesebuah organisasi sahaja, malah turut melibatkan persekitaran luaran organisasi seperti pelanggan, pembekal dan mana-mana individu atau organisasi yang dapat menyediakan sumber yang diperlukan oleh usahawan (Doganova \& Eyquem-Renault, 2009; Teece, 2010; Zott, Amit \& Massa, 2011; Zott \& Amit, 2010).

Ramai pengkaji menjelaskan bahawa jaringan sosial merupakan salah satu faktor penting dalam mempengaruhi kelestarian dalam bidang keusahawanan (Bansal, Garg \& Sharma, 2019; Evans et al., 2017; Greco \& Jong, 2017). Pengaruh jaringan sosial memberikan pelbagai manfaat kepada usahawan seperti memperoleh peluang baru, mendapatkan sumber manusia, sumber kewangan dan perkongsian ilmu dari aktor jaringan sosial yang mana memberikan peluang kejayaan dalam perniagaan (Agbim, 2019; Klyver, Honig \& Steffens, 2018; Lux et al., 2016). Walau bagaimanapun, pengaruh jaringan sosial dalam model perniagaan masih menjadi persoalan dan kajian oleh para penyelidik (Zott, Amit \& Massa, 2011). Ini menjelaskan bahawa perlunya suatu kajian yang menyeluruh dalam menyelidiki jenis 
jaringan sosial yang terlibat dalam pembentukan sebuah model kelestarian perniagaan (Schaltegger, Hansen \& Lüdeke-freund, 2016) dan apakah implikasi nilai jaringan sosial (Evans et al., 2017). Rumusannya, kajian ini bertujuan membincangkan pembentukan model perniagaan yang dipengaruhi oleh jaringan sosial. Kajian ini memberikan tumpuan terhadap proses pembentukan nilai dan impak jaringan sosial dalam membina sebuah model kelestarian perniagaan.

\section{Kajian Literatur}

\section{Konsep Model Kelestarian Perniagaan}

Konsep model kelestarian perniagaan membincangkan secara rasional bagaimana sesebuah organisasi perniagaan dibina, menerima dan memanfaatkan nilai dalam ekonomi, budaya atau lain-lain konteks, dengan cara yang lestari (Nosratabadi et al. 2019). Sebuah model perniagaan didefinisikan sebagai sebuah reka bentuk atau seni bina dalam proses menjana nilai yang mana nilai tersebut dapat memberikan manfaat kepada penerima dengan menggunakan mekanisme tertentu (Teece, 2010). Pengkaji terdahulu berpendapat bahawa model perniagaan tidak hanya terbatas pada persekitaran dalaman sesebuah organisasi sahaja, malah turut melibatkan persekitaran luaran organisasi seperti pelanggan, pembekal dan mana-mana individu atau organisasi yang dapat menyediakan sumber yang diperlukan oleh usahawan (Doganova \& Eyquem-Renault, 2009; Teece, 2010; Zott, Amit \& Massa, 2011; Zott \& Amit, 2010). Model kelestarian perniagaan memberikan pelbagai kelebihan kepada organisasi perniagaan dalam mencapai matlamat pembangunan lestari dengan mengekalkan produktiviti dan keuntungan dalam perniagaan (Schaltegger, Hansen \& Lüdeke-freund, 2016). Nosratabadi et al. (2019) menjelaskan bahawa terdapat empat pendekatan dalam membina model kelestarian perniagaan iaitu mereka bentuk penawaran nilai; mereka bentuk pembinaan nilai; mereka bentuk penerimaan nilai; dan menjana kelestarian jaringan sosial dengan membina dan menerima nilai yang diperoleh melalui sosial, persekitaran dan ekonomi. Evans et al. (2017) membincangkan lima paradigma dalam mencapai kelestarian perniagaan dan salah satu paradigma tersebut ialah nilai jaringan dengan memberikan penekanan terhadap kegunaan, reka bentuk dan tadbir urus dalam sesebuah jaringan.

\section{Jaringan Sosial Dalam Model Kelestarian Perniagaan}

Jaringan sosial penting terutamanya kepada model kelestarian perniagaan dalam membina nilai yang melangkaui lingkungan organisasi, termasuklah kesemua pihak berkepentingan dan tidak hanya melibatkan pelanggan sahaja (Evans et al., 2017; Lüdeke-Freund \& Dembek, 2017; Schaltegger, Hansen \& Lüdeke-freund, 2016). Nilai jaringan melibatkan perbezaan peranan pada setiap aktor dan keperluan organisasi yang berbeza, yang mana setiap aktor memberikan sumbangan berbentuk cadangan atau pandangan yang membentuk sebuah nilai yang bermanfaat kepada ahli dalam sesebuah jaringan (Den Ouden, 2012). Doganova dan Eyquem-Renault (2009) menjelaskan bahawa jaringan sosial merupakan suatu tindakan yang inovatif yang mana terdiri dari tingkah laku yang kreatif bersama aktor jaringan sosial yang membentuk sebuah jaringan sosial yang merupakan suatu keperluan dalam membentuk model perniagaan. Model kelestarian perniagaan memerlukan nilai jaringan dari tingkah laku dan tindakan yang sistematik melalui peranan dan tanggungjawab daripada aktor jaringan (Evans et al., 2017: 605).

\section{Pembentukan Nilai Jaringan Dalam Model Kelestarian Perniagaan}

Pengkaji terdahulu menjelaskan bahawa jaringan berperanan penting dalam proses pembentukan nilai (Chesbrough \& Rosenbloom, 2002; Holm, Eriksson \& Johanson, 1999; Lepak, Smith \& Taylor, 2007; Tsai \& Ghoshal, 1998). Menurut Gummerus (2013), pembentukan nilai dibahagikan kepada dua aliran iaitu proses pembentukan nilai dan hasil nilai. Proses pembentukan nilai melibatkan aktor, aktiviti dan sumber, manakala hasil nilai dapat dijelaskan melalui bagaimana nilai yang diterima memberikan manfaat kepada penerima (Gummerus, 2013). Kajian terdahulu menjelaskan bahawa pembentukan nilai diperoleh dari persekitaran organisasi termasuk pihak berkepentingan, pembekal dan bukan hanya daripada pelanggan sahaja yang mana setiap darinya dapat menyumbangkan manfaat dari nilai yang 
dibina (Evans et al., 2017; Gummerus, 2013; Holm, Eriksson \& Johanson, 1999; Lüdeke-Freund \& Dembek, 2017; Schaltegger, Hansen \& Lüdeke-freund, 2016; Walter, Ritter \& Gemünden, 2001).

Allee $(2008,2009)$ menerangkan model nilai jaringan perniagaan dengan memberikan tumpuan pada pertukaran nilai (tangible dan intangible) samaada dalam bentuk kewangan mahupun bukan kewangan yang dikawal oleh sejumlah aktor jaringan sosial (individu atau institusi) dalam sesebuah jaringan. Menurut beliau nilai jaringan atau nilai interaksi jaringan dilihat sebagai satu set peranan dan interaksi antara individu atau institusi untuk mencapai kepentingan ekonomi dan kepentingan sosial. Bagi menganalisis nilai jaringan, pertukaran nilai tangible melibatkan transaksi formal (kontrak) yang melibatkan bahan mentah, perkhidmatan dan bukan hanya melibatkan nilai dalam bentuk fizikal sahaja, malah turut melibatkan nilai dalam bentuk pengetahuan sesuatu produk dan perkhidmatan, perkhidmatan selepas jualan atau mana-mana perkhidmatan yang memberikan keuntungan yang direkodkan dalam bentuk kontrak. Manakala, pertukaran nilai intangible melibatkan perkongsian maklumat dan pengetahuan yang berbentuk tidak formal (tiada kontrak) seperti memberikan pertolongan, membantu urusan perniagaan ke arah kebaikan dan membina hubungan sosial. Aktiviti bersama aktor jaringan bagi nilai intangible melibatkan perkongsian maklumat strategi perniagaan, perkongsian pengetahuan, saling bantu-membantu dan bekerjasama dalam menyelesaikan masalah yang dihadapi dan memberikan cadangan penyelesaian masalah kepada pihak berwajib (Allee, 2008, 2009).

Allee turut membincangkan nilai jaringan yang terdiri daripada dua sumber iaitu nilai jaringan dalaman dan nilai jaringan luaran. Nilai jaringan dalam melibatkan aktiviti yang memberikan fokus pada hubungan individu dan kumpulan yang terdapat dalam sesebuah organisasi, manakala nilai jaringan luaran melibatkan hubungan perniagaan bersama rakan perniagaan, pembekal, pelabur dan pelanggan. Nilai jaringan dalaman dan luaran berkongsi matlamat yang sama iaitu menghasilkan barangan atau manfaat kepada pengguna (Allee, 2008, 2009). Ini menjelaskan bahawa pembentukan nilai dalam model perniagaan melibatkan hubungan pertukaran dari sejumlah aktor yang pelbagai (Evans et al., 2017; Zott, Amit \& Massa, 2011) dan menjadi tugas usahawan untuk mengurus dan membentuk hubungan tersebut (Freeman, 2010).

\section{Pengaruh Kekuatan Jaringan Dalam Pembentukan Nilai Jaringan Dalam Model Kelestarian Perniagaan}

Nilai merupakan asas pada jaringan, maka memahami fungsi jaringan secara keseluruhannya merupakan asas dalam memahami bagaimana dan kenapa nilai dibina. Allee (2008) menjelaskan terdapat tiga elemen dalam strategi nilai jaringan iaitu peranan, aktiviti dan penerimaan. Elemen peranan dapat dijelaskan melalui peranan aktor jaringan sosial (individu, komuniti dan institusi) yang dapat memberikan sumbangan dan memiliki fungsi melalui tindakan, interaksi, nilai dan boleh membuat keputusan. Elemen aktiviti melibatkan hubungan langsung antara aktor jaringan sosial yang masing-masing memiliki peranan dalam menjana nilai pertukaran (tangible dan intangible). Manakala elemen penerimaan merupakan suatu output sama ada berbentuk fizikal atau bukan fizikal seperti pengetahuan, kepakaran, nasihat, maklumat yang memberikan manfaat kepada individu atau organisasi (Allee, 2008).

Maka, dalam konteks kajian ini nilai jaringan (tangible dan intangible) dapat dijelaskan melalui proses sosial dengan memberikan tumpuan pada kekuatan pertalian jaringan yang melibatkan pertalian kuat (primer) dan pertalian lemah (sekunder) dengan melihat pada peranan, aktiviti dan manfaat yang diperoleh dari setiap aktor jaringan sosial yang dimiliki sepertimana yang dibincangkan oleh Jack (2005). Kekuatan pertalian (strenght of ties) dalam jaringan sosial didefinisikan sebagai hubungan yang kuat atau intensiti dan berkualiti atau kepelbagaian yang dapat dibezakan dengan pertalian lemah dan pertalian kuat yang berasaskan pada tempoh masa, emosi dalam perhubungan, keakraban dan hubungan timbal-balik (Granovetter, 1973). Menurut Granovetter (1973), pertalian kuat dapat dijelaskan melalui hubungan antara individu yang memiliki tahap emosi yang tinggi atau hubungan yang rapat dan wujudnya interaksi yang kerap untuk menghasilkan hubungan yang saling mempercayai. Manakala, pertalian lemah merupakan hubungan antara individu yang memiliki tahap emosi yang rendah atau tidak rapat dan kurang berinteraksi antara satu sama lain. Beliau turut 
menjelaskan bahawa jaringan perlu terdiri dari rangkaian kuat dan rangkaian lemah kerana merupakan sifat semula jadi jaringan dalam mempengaruhi operasi dan struktur jaringan (Granovetter, 1973). Oleh yang demikian, tumpuan pada kekuatan pertalian memberikan pemahaman tentang hubungan pertukaran yang melibatkan aktiviti dan peranan setiap aktor jaringan sosial (pertalian kuat dan pertalian lemah) dalam sesebuah jaringan perniagaan dan dapat menjelaskan secara mendalam pengaruh jaringan sosial terhadap kelestarian perniagaan.

\section{Metod Kajian}

Kajian ini dilakukan pada pertengahan tahun 2018. Kajian ini adalah kajian kualitatif yang menggunakan pendekatan fenomenologi untuk meneroka faktor penolakan perkhidmatan sokongan kerajaan dalam kalangan usahawan di Kuala Terengganu. Fokus utama dalam pendekatan fenomenologi ialah untuk menghuraikan dan mempreskripsikan pengalaman dan pengetahuan aktor sosial tentang sesuatu konsep berdasarkan pandangan dunia mereka dan bukannya pandangan dan persepsi penyelidik. Temu bual antara pengkaji dan informan ini memberi fokus terhadap peranan jaringan sosial, kegunaan dan proses pembentukan jaringan yang memberikan kesan kepada kelestarian perniagaan. Temu bual mendalam dan pemerhatian tidak turut serta telah dilakukan dengan melibatkan seramai 20 usahawan Melayu dengan menggunakan kaedah pensampelan purposive snowball. Kaedah snowball membolehkan pengkaji mendapatkan informan yang berpotensi dengan bantuan informan yang sedia ada dengan memperkenalkan pengkaji kepada rakan perniagaan yang mereka kenali. Dalam masa yang sama, kaedah ini membuka peluang kepada pengkaji untuk menyelidiki jaringan perniagaan usahawan Melayu. Pengkaji telah menetapkan bahawa usahawan yang layak untuk menjadi informan dalam kajian ini sekurang-kurangnya mengupah seorang pekerja dengan hasil perolehan pendapatan tahunan minimum RM300,000. Saiz syarikat yang berbeza dan jenis perniagaan yang tidak menumpu pada bidang perniagaan tertentu tidak menimbulkan persoalan kerana kajian ini ingin meneliti sistem sosial dan keusahawanan. Perbezaan ini memberi satu kelebihan untuk meneliti sistem pengurusan dalam syarikat mikro, kecil dan sederhana. Jenis perniagaan yang berbeza membuka peluang pada penelitian corak budaya yang menarik dalam sektor perniagaan yang berbeza. Kaedah temu bual mendalam dengan menggunakan pita rakaman suara dilaksanakan kerana kaedah ini dapat merangsang satu perbualan yang panjang dengan memberi peluang kepada informan untuk meluahkan pengalaman dan pendapat mereka. Kesemua temu bual disalin semula dan diformatkan untuk dimasukkan ke dalam pangkalan data Atlas.ti dan digunakan untuk membuat kategori dan indeks data. Kaedah ini juga membolehkan pengkaji mengkategorikan tema-tema dengan rapi, sistematik dan membolehkan pemprosesan dan analisis data dilakukan dengan teliti. Bagi menjaga maklumat peribadi informan, nama informan digantikan dengan $\mathrm{P}$ (participant).

\section{Hasil Kajian}

Hasil kajian dari data temu bual mendalam mempersembahkan nilai jaringan sosial (tangible dan intangible) dalam kelestarian perniagaan kecil dan sederhana Melayu yang dibahagikan kepada dua iaitu nilai jaringan primer dan nilai jaringan sekunder. Analisis pertukaran nilai jaringan (tangible dan intangible) memberikan tumpuan peranan, aktiviti dan manfaat dalam kalangan aktor jaringan sosial. Bagi menganalisis nilai jaringan, pertukaran nilai tangible melibatkan transaksi formal (kontrak) yang melibatkan bahan mentah, perkhidmatan dan bukan hanya melibatkan nilai dalam bentuk fizikal sahaja, malah turut melibatkan nilai dalam bentuk pengetahuan sesuatu produk dan perkhidmatan, perkhidmatan selepas jualan atau mana-mana perkhidmatan yang memberikan keuntungan yang direkodkan dalam bentuk kontrak. Manakala, pertukaran nilai intangible melibatkan perkongsian maklumat dan pengetahuan yang berbentuk tidak formal (tiada kontrak) seperti memberikan pertolongan, membantu urusan perniagaan ke arah kebaikan dan membina hubungan sosial. Aktiviti bersama aktor jaringan bagi nilai intangible melibatkan perkongsian maklumat strategi perniagaan, perkongsian pengetahuan, saling bantu-membantu dan bekerjasama dalam menyelesaikan masalah yang dihadapi dan memberikan cadangan penyelesaian masalah kepada pihak berwajib (Allee, 2008). Menurut Allee (2009), jaringan sosial melalui peranan dan nilai interaksi dan fungsi yang berbeza antara aktor jaringan sosial (individu atau institusi) mampu memberikan impak yang positif kepada 
DOI: https://doi.org/10.47405/mjssh.v6i9.1053

organisasi perniagaan seperti sumber kewangan, maklumat dan sokongan. Nilai jaringan melibatkan perbezaan peranan pada setiap aktor dan keperluan organisasi yang berbeza, yang mana setiap aktor memberikan sumbangan dalam bentuk cadangan atau pandangan yang membentuk sebuah nilai yang bermanfaat kepada ahli dalam sesebuah jaringan (Den Ouden, 2012).

Rajah 1: Model Kelestarian Perniagaan Usahawan Melayu

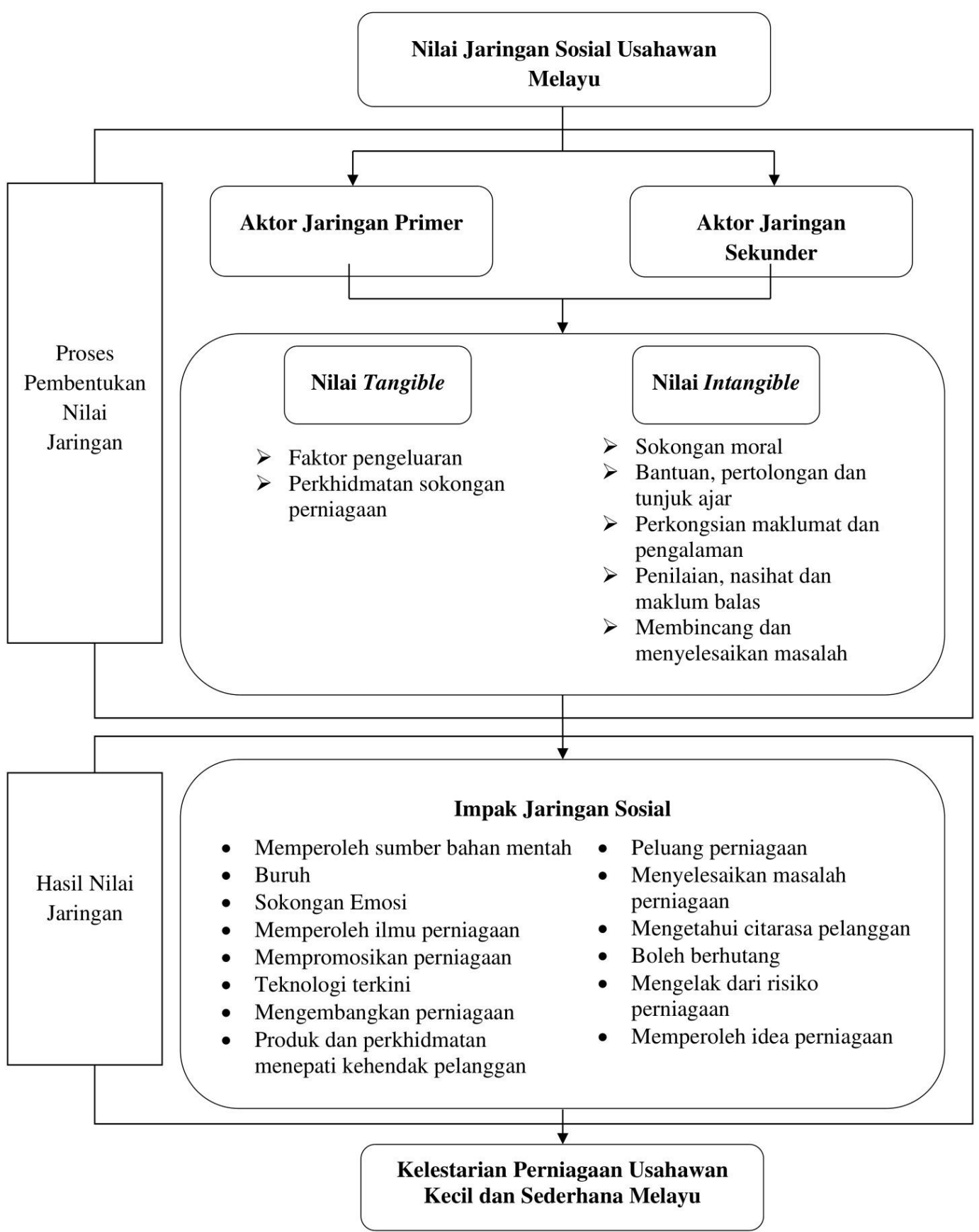

\section{Nilai Jaringan Primer}

Nilai jaringan primer atau jaringan pertalian kuat dalam kajian ini adalah keluarga (suami isteri, ibu bapa, adik-beradik, anak, saudara mara), kawan rapat, kawan jaringan perniagaan, pembekal, pekerja, pelanggan, mentor dan rakan kongsi. 
DOI: https://doi.org/10.47405/mjssh.v6i9.1053

\section{Nilai Jaringan Tangible Bagi Aktor Jaringan Primer}

\section{Faktor Pengeluaran}

\section{Memperoleh Sumber Bahan Mentah}

Walaupun pembekal merupakan individu yang tidak terlibat secara langsung dalam aktiviti perniagaan, tetapi peranan yang dimainkan oleh mereka sangat penting bagi kelangsungan perniagaan. Hasil kajian menunjukkan bahawa hubungan yang rapat antara informan dengan pembekal membolehkan informan mendapatkan sumber bahan mentah dengan cara berhutang. Berikut merupakan kenyataan informan:

"Modal saya bina dari segi kepercayaan. Disebabkan pembekal-pembekal percaya kepada saya, jadi pembekal-pembekal beri hutang dahulu tetapi bila waktu bayar saya akan bayar tepat pada masa yang dijanjikan. Atas nilai kepercayaan, saya dapat menjalankan perniagaan dengan dibantu oleh pembekal. Pembekal percaya dengan sikap saya, pembekal berani untuk memberikan bantuan. Pembekal bagi hutang atas nilai kepercayaan" (P6)

"Pembekal mempercayai saya dengan memberi hutang kepada saya. Saya meminta tulis dalam buku hutang dahulu dan dia setuju. Dia percaya kepada saya sebab saya dah lama berurusan dengan dia. Awal berniaga dia tak bagi hutang tetapi bila dah lama berurus niaga dia bagi saya hutang" (P11)

Nilai kepercayaan menjadi keutamaan dalam sebuah hubungan pertalian kuat. Hubungan rapat antara informan dengan pembekal terbina melalui kekerapan dalam perhubungan yang melibatkan urusan perniagaan. Ini membolehkan wujudnya urus niaga yang dibina atas dasar saling mempercayai. Kesannya, informan dalam kajian ini boleh menjalankan aktiviti perniagaan dengan mendapatkan sumber bahan mentah daripada pembekal dengan cara berhutang. Pemberian hutang yang fleksibel daripada pembekal memberikan membantu informan meneruskan aktiviti perniagaan dan kelangsungan perniagaan.

\section{Buruh}

Pekerja dan rakan kongsi merupakan individu yang rapat dengan usahawan dan merupakan tulang belakang pada kejayaan sesebuah perniagaan. Usahawan bertanggungjawab dalam membentuk dan menguruskan sebuah organisasi yang memiliki sekelompok manusia yang berfungsi secara berkumpulan dan setiap dari mereka memiliki pengkhususan kerja yang jelas. Dapatan kajian mendapati pekerja dan rakan kongsi memainkan peranan yang penting dalam membantu informan menguruskan perniagaan. Berikut merupakan kenyataan informan:

"Pada peringkat awal saya buat semua perkara, sekarang saya serah semuanya kepada pekerja mengikut bahagian. Kita kena bagi kepercayaan kepada orang lain. Kalau semua orang kita tak percaya, kita tidak boleh berniaga" (P6)

"Pemilik syarikat tak boleh bergerak sendiri. Perlukan pekerja berpasukan. Kalau tak ada pekerja berpasukan, perniagaan tidak akan berjaya. Pekerja perlu ada sikap jujur, amanah, setia pada syarikat. Disiplin dan sikap yang diambil kira dalam pemilihan staf. Saya urus bahagian pengurusan sahaja. Saya juga belajar dengan staf bersama-sama. Saya memilih pekerja yang betul-betul boleh buat kerja sebab tugas dia untuk membantu urusan syarikat" (P12)

"Disebabkan saya tak dapat nak uruskan semua kerja jadi saya terpaksa ambil rakan kongsi untuk dia urus kedai. Saya dah lama kenal dia sejak zaman sekolah lagi. Saya perlukan rakan kongsi yang boleh jaga staf dan pelanggan saya, bagi semangat kepada staf, ada strategi dan sebagainya. Saya juga tengok latar belakang dia seperti pengetahuan dia seperti adanya ilmu sumber manusia dan 
pandai cari peluang baru. Dia pesara kerajaan dan saya minta dia urus bahagian urus niaga berkaitan kerajaan sebab dia ada kepakaran di bahagian itu. Saya bagi 10 peratus saham syarikat sebab sekarang saya diperingkat tepu dan tiada idea baru dalam perniagaan" (P12)

Kenyataan di atas menjelaskan bahawa bagi membina sebuah perniagaan yang berjaya informan perlu membina hubungan yang rapat bersama pekerja dan rakan kongsi. Perniagaan yang berjaya memerlukan pembahagian kerja yang jelas dan melakukan kerja secara berpasukan. Pengagihan tugas yang jelas dan bantuan dari pekerja dan rakan kongsi dapat melancarkan aktiviti perniagaan. Oleh yang demikian, informan dapat memberikan tumpuan sepenuhnya dalam aktiviti pengurusan dan strategi perniagaan. Segala aktiviti dan masalah yang dihadapi dibincangkan dan diselesaikan bersama.

\section{Perkhidmatan Sokongan Perniagaan (mentor)}

Ilmu pengetahuan dan kemahiran yang dimiliki oleh usahawan adalah terhad. Oleh itu, usahawan memerlukan individu yang boleh membimbing dan memberikan tunjuk ajar dalam menguruskan perniagaan melalui perkongsian maklumat dan pengalaman yang dimiliki. Kajian mendapati, informan mendapatkan khidmat nasihat dan bimbingan daripada individu yang memiliki pengalaman luas dalam membina dan menguruskan perniagaan dengan berjaya. Berikut merupakan kenyataan informan:

"Kelas mentor berbayar (Azizan Osman) yang saya sertai. Saya perlu hadir ke kelas-kelas selain anjuran kerajaan kerana saya rasa saya tidak boleh duduk dalam peringkat yang sama. Saya kena guna pendekatan yang baru sesuai dengan permintaan sekarang sebab orang dahulu tengok televisyen dan baca surat khabar sahaja, tetapi orang sekarang tak baca dah surat khabar, televisyen pun kadang-kadang tak tengok dah. Sebab tu saya kena perkembangan sekarang" (P5)

"Saya ada kelompok perniaga yang mana terdapat mentor yang saling berkongsi berkenaan perniagaan, maklumat terkini, pendapat dan sebagainya. Saya bayar dia RM3 ribu sebulan untuk dia bantu saya bina dan kembangkan perniagaan. Saya dapat tahu maklumat mentor tu dari internet sebab dia mentor yang profesional. Saya banyak berkongsi dan belajar dengan dia dalam 2 hingga 3 tahun" (P16)

"Masalah yang saya hadapi ini kebiasaan saya rujuk mentor saya. Dia lebih kepada usahawan sosial yang mana perniagaan dia adalah membantu perniagaan orang lain. Dia ada pengalaman berniaga hingga ke peringkat korporat. Jadi saya banyak rujuk dia" (P5)

Mentor merupakan individu yang rapat dengan informan. Ini kerana segala maklumat sulit dalam perniagaan dikongsi bersama antara informan dengan mentor. Mentor merupakan seorang individu yang mempunyai pengalaman yang luas dalam perniagaan yang mampu membimbing dan memberikan tunjuk ajar kepada usahawan dalam menguruskan perniagaan. Maka, mentor merupakan sumber rujukan utama terutama ketika informan menghadapi masalah dalam perniagaan.

\section{Nilai Jaringan Intangible Bagi Aktor Jaringan Primer}

\section{Sokongan Moral}

Sokongan moral diperlukan ketika usahawan berhadapan dengan masalah dalam perniagaan. Pemberian kata-kata semangat dan sokongan emosi sangat diperlukan oleh usahawan terutama ketika berhadapan dengan masalah dalam perniagaan. Hasil kajian mendapati informan menerima sokongan sosial daripada individu yang berada di sekeliling informan seperti ahli keluarga dan rakan jaringan perniagaan. Berikut merupakan kenyataan informan: 


\begin{abstract}
"Abang saya memahami saya, dia selalu bagi sokongan moral. Kadang-kadang saya ada juga hari kecewa dan tidak bersemangat. Jadi kadang-kadang abang saya telefon tanya khabar" (P9)

"Sumbangan paling banyak adalah kata-kata semangat. Saya timbul semangat untuk teruskan bidang penternakan lembu ni juga hasil dari semangat yang diberikan dari kawan-kawan. Pertolongan duit sahaja tidak cukup kalau semangat kita tidak kuat. Bila kawan-kawan memberikan semangat, kita jadi semakin bersemangat" (P20)
\end{abstract}

Sokongan moral boleh didapati daripada individu yang rapat dengan informan. pemberian kata-kata semangat dan sokongan dapat mengembalikan semangat dan keyakinan informan untuk meneruskan perniagaan. Sokongan moral penting bagi informan terutama ketika informan berhadapan dengan masalah dalam perniagaan.

\title{
Bantuan, Pertolongan Dan Tunjuk Ajar
}

\section{Ilmu Perniagaan}

Hasil kajian mendapati hubungan rapat bersama rakan jaringan perniagaan dan pembekal membolehkan berlakunya perkongsian ilmu perniagaan. Perkongsian ilmu perniagaan penting bagi informan untuk menguruskan perniagaan terutama dalam hal-hal perniagaan seperti pengurusan syarikat, sumber manusia, perakaunan dan strategi pemasaran. Berikut merupakan kenyataan informan:

\footnotetext{
"Saya selalu membuat lawatan ke kolam rakan-rakan saya yang juga membuat ternakan udang. Kami sering bertukar idea dan informasi" (P10)

"Saya memiliki lima pembekal yang boleh memberikan kerjasama dan jujur dalam urusan perniagaan. Saya selalunya berbincang urusan perniagaan bersama mereka Selain itu, saya juga mempunyai rakan yang turut menjalankan perniagaan bengkel kereta. Kami sering berkongsi maklumat dan kemahiran dalam urusan membaiki kereta. Jadi kami saling berkongsi ilmu" (P1)
}

Ilmu pengetahuan membimbing dan mempengaruhi informan terhadap cara berfikir dan bertindak dalam menguruskan perniagaan. Perkongsian ilmu dari kenalan jaringan sosial membantu informan merancang strategi perniagaan dengan menggunakan teknik perniagaan yang berkesan, mampu bersaing dan terus berada dalam pasaran.

\section{Mempromosikan Perniagaan}

Hubungan rapat bersama rakan jaringan perniagaan dan pelanggan mewujudkan hubungan sosial yang saling memberikan pertolongan dan bantuan seperti mempromosikan produk dan perkhidmatan informan. Berikut merupakan kenyataan informan:

"Atas nilai kepercayaan dan nilai baik yang saya ada, rakan-rakan bercerita tentang sikap saya kepada rakan-rakan yang lain. Oleh sebab itu, ramai pembekal-pembekal lain menawarkan bantuan bahan mentah kepada saya. Kawan saya yang mempromosikan jenama perniagaan saya" (P6)

"Kebiasaan pelanggan akan mempromosikan produk saya di media sosial, menulis berkenaan produk saya di dalam blog, membuat video masakan menggunakan produk saya. Agen dari luar negeri juga menjual produk saya di sekolah dan mempromosikan produk saya di dalam Facebook" (P7) 
Hubungan rapat yang dibina atas nilai kepercayaan memberikan kelebihan kepada informan terutama dalam mempromosikan produk dan perkhidmatan informan kepada orang ramai. Ini membantu informan menjimatkan masa dan kos dalam aktiviti pemasaran produk dan perkhidmatan. Perkongsian tentang kelebihan, kualiti dan kepuasan produk dan perkhidmatan daripada pelanggan dan rakan jaringan perniagaan membantu mempromosikan produk dan perkhidmatan kepada orang ramai.

\section{Teknologi Terkini}

Seiring peredaran masa, kaedah perniagaan turut berlakunya transformasi. Penggunaan aplikasi media sosial seperti Facebook dan Instagram sebagai medium dalam urusan jual beli menjadi semakin penting dalam kelangsungan perniagaan. Informan dalam kajian ini menyatakan bahawa individu yang rapat seperti anak banyak membantu urusan pemasaran produk dengan menggunakan teknologi terkini yang seiring dengan kehendak dan keberkesanan dalam aktiviti perniagaan. Berikut merupakan kenyataan informan:

"Anak-anak menggunakan teknologi dan menjual produk tersebut secara online seperti Facebook dan instagram. Dari situ pelanggan dapat kenal produk saya dan terus boleh membeli menggunakan bayaran secara atas talian dan penghantaran dilakukan melalui pos. Saya tak pandai teknologi ni. Semua saya serah ke anak. Sekarang lepas guna teknologi, jualan saya semakin meningkat sebab pelanggan lebih suka membeli secara online sebab lebih menjimatkan wang, masa dan tenaga" (P13)

Oleh kerana permintaan dan cita rasa pelanggan yang sering berubah, informan perlu memperbaiki dan menambahbaikkan kualiti produk dan perkhidmatan sedia ada agar dapat memenuhi kehendak dan cita rasa pelanggan. Bantuan dari individu yang rapat seperti ahli keluarga dapat membantu informan memasarkan produk ke seluruh dunia. Penggunaan teknologi moden dalam aktiviti pemasaran menjadi perkara utama dalam perniagaan pada masa kini.

\section{Perkongsian Maklumat Dan Pengalaman}

\section{Mengembangkan perniagaan (rakan jaringan perniagaan)}

Hubungan rapat bersama pelanggan dan kawan karib membantu informan mendapatkan maklumat yang boleh digunakan bagi mengembangkan perniagaan. Berikut merupakan kenyataan informan:

"Sekiranya saya ingin mencari pasaran dalam kerajaan, saya akan berjumpa dengan kawan yang bekerja dengan sektor kerajaan. Saya bertanya kepada kawan saya bagaimana saya boleh kembangkan perniagaan, kawan saya akan beritahu segala proses dengan betul" (P9)

"Bila saya lepak dengan pelanggan (agen), saya akan dapat sedikit maklumat. Contoh bila saya berjumpa dengan pegawai pasar raya, pegawai tersebut akan memberitahu kepada saya apa yang dilakukan oleh syarikat besar yang berjaya dalam menjual produk mereka. Dari situ saya banyak belajar perkara baru dan menggunakan maklumat tersebut dalam perniagaan saya" (P19)

Informan dalam kajian ini mendapatkan maklumat daripada individu yang rapat bagi tujuan mengembangkan perniagaan. Pengetahuan dan pengalaman yang dimiliki oleh individu yang dikenali dan rapat memudahkan aktivti pertukaran maklumat. Oleh kerana wujud kepercayaan, maklumat dan pengalaman yang dikongsi mudah diterima dan dapat menjimatkan masa, kos dan tenaga.

\section{Penilaian, Nasihat Dan Maklum Balas}

\section{Memperoleh Idea Perniagaan}


DOI: https://doi.org/10.47405/mjssh.v6i9.1053

Informan dalam kajian ini memperoleh idea perniagaan dalam bentuk cadangan dan maklum balas dari individu yang rapat bagi tujuan penambahbaikan produk dan perkhidmatan dan strategi perniagaan. berikut merupakan kenyataan informan:

"Kawan juga banyak memberi cadangan untuk meningkatkan pencapaian perniagaan termasuk kualiti produk, tempat2 berpotensi untuk menjual produk" (P5)

"Pelanggan ada juga memberikan maklum balas contohnya macam mana ni kualiti nampak terjejas je. Pelanggan memberikan maklum balas untuk bagi peringatan kepada saya. Saya sangat berterima kasih atas komen tu sebab kadang-kadang saya terlepas pandang" (P5)

Informan dalam kajian ini memperoleh idea perniagaan hasil dari perbincangan dengan rakan jaringan perniagaan yang mana turut menjalankan perniagaan yang sama dengan informan. Kawan jaringan perniagaan yang rapat merupakan individu yang paling sesuai kerana miliki pemahaman, pengalaman dan matlamat yang sama dalam perniagaan. Maklum balas dan cadangan daripada pelanggan turut membantu informan menjana idea baru dalam melakukan penambahbaikan kualiti produk dan perkhidmatan.

\section{Mengetahui Cita Rasa Pelanggan}

Maklum balas dari pelanggan penting bagi informan untuk mengetahui tahap kepuasan dan cita rasa pelanggan terhadap produk dan perkhidmatan yang ditawarkan. Hasil dari maklum balas tersebut, informan dapat mengetahui kekurangan dan kelemahan pada produk dan perkhidmatan yang ditawarkan. Dalam masa yang sama, informan turut meminta cadangan bagi tujuan penambahbaikan produk dan perkhidmatan tersebut.

"Pelanggan ada juga memberikan maklum balas contohnya macam mana ni kualiti nampak terjejas je. Pelanggan memberikan maklum balas untuk bagi peringatan kepada saya. Saya sangat berterima kasih atas komen tu sebab kadang-kadang saya terlepas pandang" (P5)

Maklum balas daripada pelanggan penting bagi informan untuk menghasilkan produk yang berkualiti, memenuhi cita rasa dan kepuasan pelanggan dan mampu menyelesaikan masalah pelanggan hasil dari penggunaan produk dan perkhidmatan yang dihasilkan oleh informan.

\section{Mengelak Dari Risiko Perniagaan}

Kenalan jaringan yang berpengalaman dapat membantu informan mengelak dari sebarang risiko kerugian dalam perniagaan melalui perkongsian maklumat dan nasihat. Informan dalam kajian ini mendapatkan maklumat dan nasihat dari kenalan jaringan yang berpengalaman sebelum membuat apaapa keputusan dalam aktiviti perniagaan.

"Saya pernah ditawarkan untuk menyertai pameran di luar negara. Setelah berbincang dengan kawan sebab kawan saya sudah menyertai pameran tersebut. Kawan saya tidak galakkan saya untuk sertai program tersebut sebab banyak belanja dan berisiko tinggi dan boleh memberikan kerugian yang besar. Pihak agensi pula hanya bantu separuh dari kos tersebut. Disebabkan saya kena ambil kira pelbagai kos seperti kos penginapan pekerja, makan minum dan lain-lain, saya tidak sertai program tersebut" (P11)

Rakan jaringan perniagaan merupakan kenalan jaringan kuat yang selalu memberikan maklumat dan nasihat dalam aktiviti perniagaan. Oleh kerana kawan jaringan perniagaan mengusahakan jenis perniagaan yang sama dengan informan, mereka mudah untuk berkongsi maklumat dan risiko-risiko yang bakal berlaku pada setiap tindakan yang dilakukan dalam perniagaan. Oleh itu, mendapatkan 
DOI: https://doi.org/10.47405/mjssh.v6i9.1053

maklumat dan nasihat daripada kenalan jaringan sosial yang berpengalaman mampu menghindarkan informan dari risiko-risiko yang boleh membawa kerugian pada perniagaan informan.

\section{Membincang dan Menyelesaikan Masalah}

\section{Menyelesaikan Masalah Perniagaan}

Informan dalam kajian ini berbincang dan menyelesaikan masalah dengan individu yang rapat seperti pekerja. Selain itu, rakan jaringan perniagaan yang rapat turut membantu informan menyelesaikan masalah dengan membincang masalah dan memberikan cadangan dalam menyelesaikan masalah yang dihadapi. Berikut merupakan kenyataan informan:

"Masalah tentang perniagaan saya akan panggil ketua penyelia untuk berbincang dan selesaikan masalah yang dihadapi. Perlu ada sentiasa perbincangan dengan pekerja. Saya berbincang masalah dengan para pekerja dengan memberikan nasihat dan maklumat tentang perniagaan. Dalam perniagaan, hubungan saya banyak dengan pekerja" (P6)

"Kebiasaan masalah yang saya hadapi ini saya akan berbincang atau minta nasihat dengan kawan perniagaan terdekat. Ramai lagi kawan-kawan lain dan saya juga ada kawan-kawan yang lebih berumur yang juga melakukan perniagaan dan berjaya. Dia yang berumur ni dah banyak pengalman dalam perniagaan dan juga membantu memberikan nasihat dan tunjuk ajar kepada saya" (P15)

Rakan jaringan perniagaan yang rapat merupakan sumber rujukan utama bagi informan dalam kajian ini. Ini kerana rakan jaringan perniagaan merupakan individu yang paling sesuai untuk membincangkan urusan perniagaan kerana turut menjalankan perniagaan. Mereka saling memahami kerana berada dalam bidang yang sama. Selain itu, mereka kerap berjumpa dan berhubung melalui penglibatan dalam kursus dan latihan, ekspo keusahawanan dan sebagainya. Mendapatkan nasihat, cadangan, perkongsian ilmu, maklumat dan tunjuk ajar merupakan matlamat informan berhubungan dengan kenalan jaringan sosial.

\section{Nilai Jaringan Sekunder}

Nilai jaringan sekunder atau jaringan pertalian lemah dalam kajian ini adalah agensi kerajaan, agensi swasta, institusi kewangan, persatuan, pelanggan, pembekal dan kawan jaringan perniagaan.

\section{Nilai Jaringan Tangible Bagi Aktor Jaringan Sekunder}

\section{Faktor Pengeluaran}

\section{Sumber Kewangan}

Hasil kajian mendapati terdapat dua sumber kewangan yang digunakan oleh informan untuk mengusahakan perniagaan iaitu melalui agensi kerajaan dan bank. Majoriti informan dalam kajian ini memulakan perniagaan dengan modal sendiri. Selain menggunakan simpanan sendiri, informan turut membuat pinjaman wang daripada kalangan keluarga. Bagi mengembangkan perniagaan, informan memerlukan modal yang besar dan perlu membuat pinjaman sama ada dari pihak agensi kerajaan ataupun bank. Berikut merupakan kenyataan informan:

"Mesin RM300 ribu saya buat pinjaman dari MARA dan bayar setiap bulan. Memudahkan saya sebab selepas 2 bulan beroperasi baru saya perlu mula bayar balik pinjaman tersebut" ( $\mathrm{P} 4)$ 
"Pihak MARA akan membayar keseluruhan jumlah kos sesuatu projek dengan membayar penuh. Jadi saya tidak perlu bersusah-bersusah untuk mencari modal untuk menyiapkan projek yang saya dapat tersebut" (P11)

Kenyataan di atas menjelaskan bahawa pihak kerajaan menyediakan pinjaman bagi memudahkan urusan perniagaan. Pihak kerajaan memberikan kemudahan dengan menawarkan kaedah bayaran balik mengikut kemampuan informan. Kaedah bayaran balik yang fleksibel dapat membantu informan merancang aktiviti perniagaan yang lebih bersistematik dan dapat mengelak daripada muflis. Bantuan pinjaman dari pihak kerajaan juga dapat membantu usahawan menyelesaikan masalah untuk mendapatkan modal perniagaan.

Bagi pinjaman dari pihak bank, pinjaman dilakukan ketika informan ingin mengembangkan perniagaan. Berikut merupakan kenyataan informan:

"Di awal perniagaan saya tidak membuat pinjaman bank. Pinjaman bank dibuat pada peringkat perkembangan perniagaan" (P6)

"Saya membuat pinjaman dengan Agro Bank. Saya bayar mengikut jadual yang ditetapkan. 3 hingga 4 tahun sebelum habis bayaran pinjaman, pihak bank akan tawarkan pinjaman baru kepada saya. Sekarang pihak bank sudah yakin dengan perniagaan saya. Jika saya tidak buat permohonan baru, pihak bank akan cari saya untuk minta saya buat pinjaman baru. Pihak bank juga sanggup membantu membuat kertas kerja baharu untuk memudahkan pinjaman diluluskan. Pada awal mula nak berniaga, susah untuk pihak bank luluskan pinjaman sebab masih ragu-ragu dan tidak yakin dengan perniagaan saya" (P10)

Penambahbaikan infrastruktur, premis perniagaan, pertambahan kakitangan dan penggunaan bahan mentah yang berkualiti memerlukan modal yang besar. Oleh itu, bagi tujuan mengembangkan perniagaan, informan perlu membuat pinjaman dengan pihak bank. ini kerana pada peringkat mengembangkan perniagaan, profil syarikat telah kukuh dan ini memberikan keyakinan kepada pihak bank untuk menawarkan pinjaman kepada informan. Selain itu, perkhidmatan dari pihak bank yang memudahkan urusan kelulusan pinjaman telah menarik minat informan untuk mendapatkan pinjaman dari pihak bank.

\section{Perkhidmatan Sokongan Perniagaan (kursus dan latihan/ ekspo dll)}

Kursus dan latihan tidak hanya disediakan oleh pihak kerajaan, terdapat agensi swasta yang menyediakan kursus dan latihan bagi tujuan membantu usahawan menjalankan perniagaan. Kebiasaannya, kursus dan latihan yang disediakan pihak swasta adalah berbayar. Hasil temu bual kajian ini mendapati terdapat informan yang menyertai kursus dan latihan yang dianjurkan oleh pihak swasta. Kenyataan ini dapat dijelaskan melalui petikan di bawah:

"Pernah menyertai kursus di Pulau Redang anjuran syarikat pembekal makanan ayam (Kuantan). Kursus berkenaan mengenal pasti penyakit ayam dan cara merawat. Kursus ini saya dapat tahu dari pembekal sendiri. Pembekal bukan hanya membekalkan keperluan makanan dan anak ayam, tetapi turut menjalankan kursus dan latihan" (p2)

"Selepas saya pergi belajar ke kelas pengurusan perniagaan dari pihak swasta, baru saya tahu apa yang diperlukan dalam perniagaan. Kursus pengurusan di bawah agensi kerajaan ada tetapi masa itu saya tidak ada kesedaran lagi untuk mengikuti kursus tersebut atau mungkin sebab percuma jadi saya tidak berminat dan bersungguh untuk belajar. Selepas saya sertai kursus berbayar, baru saya hargai dan dapat tahu keperluan sebenar dalam perniagaan" (P19) 
Menurut informan, mereka menyertai kursus dan latihan yang dianjurkan oleh pihak swasta kerana mereka menerima tunjuk ajar dan ilmu perniagaan yang lengkap. Pengisian kursus dan latihan dari pihak swasta berbeza dengan kursus dan latihan dari pihak kerajaan. Pihak kerajaan hanya menyediakan kursus dan latihan asas dan tidak lengkap. Ini menyebabkan informan tidak mendapat ilmu perniagaan yang mencukupi untuk menjalankan perniagaan. Selain itu, cara penyampaian dan penerimaan ilmu adalah berbeza dari pihak swasta dan pihak kerajaan. Pihak swasta akan menggunakan cara penyampaian ilmu yang kreatif. Melalui kursus dan latihan dari pihak swasta, informan menyatakan mereka berkeyakinan dan berani untuk mengembangkan perniagaan.

Kerajaan turut menawarkan perkhidmatan sokongan perniagaan kepada usahawan. Tidak semua bantuan yang disediakan adalah percuma. Oleh kerana jumlah usahawan yang ramai dan jumlah peruntukan yang terhad, informan dalam kajian ini masih mendapat peluang bantuan daripada pihak kerajaan dengan hanya membayar sebahagian dari jumlah kos yang sebenar. Berikut merupakan kenyataan informan:

"Yayasan Pembangunan Usahawan (YPU) membantu untuk mendapatkan label nutrient food pada produk dengan bayaran sebanyak lima puluh peratus dari harga sebenar dan selebihnya akan dibayar oleh pihak YPU. SME Bank membantu saya mendapatkan 3 jenis mesin yang bernilai RM80 ribu dan saya hanya membayar sebanyak dua puluh peratus sahaja dari harga asal" (P7)

"Saya mula membina perniagaan ini pada tahun 2013. Ladang ternakan udang ini mula-mula adalah kawasan hutan paya. Tanah ini asalnya tanah milik Jabatan Perikanan. Setelah saya membuat pembentangan kertas kerja, saya dapat menggunakan tanah ini untuk mengusahakan ternakan udang ini selama 20 tahun mengikut perjanjian" (P10)

Bagi menguruskan perniagaan yang berjaya, usahawan memerlukan perbelanjaan yang besar. Oleh itu, bantuan dari pihak kerajaan sangat diperlukan bagi menghasilkan produk dan perkhidmatan yang berkualiti dengan menggunakan sejumlah sumber bahan mentah dan infrastruktur yang berkualiti. Bagi pembekal pula, perkhidmatan sokongan perniagaan ditawarkan melalui perkhidmatan selepas jualan. Berikut merupakan kenyataan informan:

"Saya memilih untuk mengambil mesin dari Taiwan. Saya menjaga hubungan baik dengan pembekal dari Taiwan ini. Tujuan saya berhubung baik dengan mereka kerana saya memerlukan khidmat lepas jualan dari mereka. Kadangkadang mesin rosak dan perlu dibaiki. Disebabkan hubungan baik saya dengan mereka, saya dapat kurangkan kos pembaikian mesin kerana saya meminta mereka datang membaiki mesin semasa mereka mengadakan pameran mesin di Kuala Lumpur. Kalau saya tidak menjaga hubungan baik dengan mereka, saya perlu berbelanja besar untuk panggil mereka dari Taiwan semata-mata untuk membaiki mesin saya" (P8)

Perkhidmatan lepas jualan merupakan aspek yang dititikberatkan oleh informan dalam pemilihan pembekal. Contohnya, penggunaan mesin memerlukan pemeriksaan berkala bagi memastikan mesin sentiasa dapat berfungsi dengan baik agar operasi pengeluaran produk dan perkhidmatan berjalan lancar. Sebaliknya, pembekal yang bermasalah dalam memberikan perkhidmatan akan mengganggu operasi pengeluaran dan memberikan kerugian kepada informan.

\section{Nilai Jaringan Intangible Bagi Aktor Jaringan Sekunder}

\section{Bantuan, Pertolongan Dan Tunjuk Ajar}

\section{Ilmu Perniagaan}


Kerajaan menyediakan kursus dan latihan dalam membantu usahawan. Bantuan keperluan asas seperti tapak premis, infrastruktur dan pelbagai geran dapat membantu usahawan membina sebuah perniagaan. Salah satu usaha yang dilakukan oleh kerajaan dengan menyediakan kursus dan latihan kepada usahawan. Kursus dan latihan yang disediakan merangkumi segala aspek dalam perniagaan bermula dari peringkat membina sehingga mengembangkan perniagaan. Berikut merupakan kenyataan informan:

"YPU memberikan kursus berkenaan syarikat seperti kursus akaun, cara buat kertas kerja, pelanggan, marketing dan sebagainya. Kursus di YPU juga penting sebab mengajar cara membuat kertas kerja. Kemahiran dalam membuat kertas kerja ni penting untuk mohon geran. Selepas saya sertai kursus buat kertas kerja tu saya boleh dah buat kertas kerja" (P10)

"Saya sertai Persatuan Peladanita. Banyak aktiviti dan kursus yang boleh membantu mengembangkan perniagaan dalam kalangan wanita" (P17)

Kenyataan informan di atas menjelaskan bahawa informan memperoleh ilmu perniagaan setelah menyertai kursus dan latihan yang dianjurkan oleh pihak kerajaan. Melalui kursus dan latihan, informan dapat mempelajari segala aspek dalam pengurusan perniagaan dan dapat mengenal pasti kesilapan-kesilapan dalam perniagaan.

\section{Mempromosi Perniagaan}

Bantuan dari agensi kerajaan dapat mempromosikan produk dan perkhidmatan informan kepada orang ramai melalui penyertaan program keusahawanan yang dianjurkan oleh pihak kerajaan. Berikut merupakan kenyataan informan:

"YPU banyak buat ekspo keusahawanan di Terengganu dan luar Terengganu. YPU akan ajak usahawan untuk sertai ekspo tu. Saya ikut ekspo untuk perkenalkan produk saya. Saya hadapi masalah pasarkan produk, jadi saya bincang dengan keluarga dan YPU. Pihak Ypu minta saya sertai ekspo seperti di Johor, Kuala Lumpur, Terengganu untuk kenalkan produk kepada orang ramai. YPU sediakan tempat pameran. Bayaran adalah percuma. KPDNKK pula memberikan tawaran untuk mempromosikan demo masakan produk saya di TV3 dalam program jom singgah" (P7)

Melalui penglibatan usahawan dalam program-program pameran anjuran kerajaan, orang ramai dapat mengetahui tentang produk dan perkhidmatan yang ditawarkan oleh informan. Hubungan baik dengan pihak kerajaan juga boleh terjalin dengan menyertai tempat-tempat pameran yang dianjurkan oleh pihak kerajaan. Usahawan mengekalkan hubungan baik bersama pihak kerajaan bagi tujuan kelangsungan perniagaan.

\section{Teknologi Terkini}

Teknologi yang semakin berkembang dan semakin canggih memerlukan usahawan melakukan perubahan dalam perniagaan agar mampu menghasilkan produk yang berkualiti dan mampu bersaing dalam pasaran. Bagi mencapai matlamat tersebut, usahawan perlu menambahkan ilmu perniagaan. Informan dalam kajian ini menyertai kursus dan latihan yang dianjurkan oleh agensi kerajaan dan persatuan. Bermula dari penggunaan mesin yang berteknologi tinggi sehinggalah menggunakan teknologi dalam aktiviti pemasaran produk dan perkhidmatan. Berikut merupakan kenyataan informan:

"Sekarang saya baru terlibat dalam urusan jualan secara atas talian sebab mendapat banyak permintaan dari pelanggan yang ingin membeli secara atas talian" (P6) 
"Saya pergi kursus dan latihan yang disediakan oleh pihak agensi. Kursus itu mengajar saya semua berkaitan dengan perniagaan yang sangat membantu saya dalam menjalankan perniagaan. Saya perlu mengikuti kursus-kursus untuk menambah ilmu pengetahuan sebab sistem selalu berubah. Contoh teknologi komputer" (P8)

Oleh kerana permintaan dan cita rasa pelanggan yang sering berubah, informan perlu memperbaiki dan menambahbaikkan kualiti produk dan perkhidmatan sedia ada agar dapat memenuhi kehendak semasa dan cita rasa pelanggan. Oleh itu, informan dalam kajian ini menghadiri kursus dan latihan yang dianjurkan oleh agensi kerajaan bagi tujuan mempelajari teknologi terkini yang dapat digunakan dalam perniagaan mereka.

\section{Perkongsian Maklumat dan Pengalaman}

\section{Mengembangkan Perniagaan}

Informan dalam kajian ini dapat mengembangkan perniagaan hasil dari penyertaan kursus, latihan dan seminar keusahawanan yang dianjurkan oleh agensi kerajaan dan membina hubungan bersama rakan jaringan perniagaan.

"Kawan-kawan banyak berkongsi maklumat dengan saya. Contoh pengalaman untuk mengeksport produk ke luar negara" (P4)

"Saya menyertai kursus dan latihan dari MARDI dan MARA. Saya sertai kursus tersebut dari awal perniagaan dan di peringkat mengembang dan mengekalkan perniagaan. Mereka ajar cara buat akaun, 5s (pengurusan fail), cara membuat promosi melalui Facebook, online dan lain-lain. Biasa kursus selalu ada, kalau terlepas mereka akan buat lagi” (P4)

"YPU panggil penjual atau pihak pasar raya untuk buat jaringan perniagaan bersama usahawan Terengganu. Bincang macam mana nak masukkan produkproduk orang Melayu ke pasar raya dia (business matching). Usahawan boleh jumpa dan bincang secara langsung dengan pihak pasar rayat. Jadi usahawan dapat tahu apa kriteria yang diperlukan untuk dapatkan pasaran di pasar raya pemilik penjual tersebut" (P7)

Kelebihan yang diperoleh dari membina hubungan jaringan sosial bersama agensi kerajaan bukan hanya boleh mendapatkan maklumat, nasihat, dan pinjaman wang sahaja, malah informan dalam kajian ini dapat mengembangkan perniagaan dengan bantuan dari pihak kerajaan. Dalam kajian ini, agensi kerajaan iaitu YPU menjadi perantara dalam membina program kerjasama atau business matching antara informan dengan pihak premis perniagaan. Hasil program ini memberikan maklumat kepada informan tentang kriteria-kriteria yang diperlukan untuk memasuki pasaran di premis-premis perniagaan tersebut. Program ini membantu informan melakukan penambahbaikan produk dan perkhidmatan yang menepati kehendak pasaran dan sekali gus mampu mengembangkan perniagaan. Selain membina hubungan jaringan sosial bersama agensi kerajaan, informan dalam kajian ini turut membina mendapat manfaat dari rakan jaringan perniagaan hasil dari perkongsian pengalaman dalam mengusahakan perniagaan.

\section{Peluang Perniagaan}

Hasil dari kajian ini menemui bahawa informan dalam kajian ini memperoleh maklumat berkenaan peluang perniagaan daripada aktor jaringan lemah seperti agensi kerajaan, kawan jaringan perniagaan dan persatuan. Hasil penyertaan seminar keusahawanan, kursus dan latihan yang dianjurkan oleh agensi kerajaan dan persatuan, informan mendapat maklumat berkenaan peluang-peluang dalam perniagaan dan dalam masa yang sama dapat berkenalan dan membina hubungan sosial bersama 
usahawan lain yang berlainan latar belakang dan pengalaman dan seterusnya membina hubungan jaringan perniagaan.

"Saya kenal rakan perniagaan semasa pertemuan di ekspo keusahawanan dan kami di bawah agensi yang sama. Kadang-kadang berjumpa semasa mesyuarat dan berbincang bersama-sama" (P3)

"Networking dalam persatuan hanya berkongsi maklumat-maklumat tender. Bila ada tender baru buka, kami berkongsi maklumat dan memohon tender tersebut" (P16)

"YPU berperanan kenalkan saya dengan pembekal sabut, tolong beritahu agensi-agensi yang sepatutnya saya jumpa. Saya minta tolong pihak YPU temukan saya dengan agensi-agensi terlibat. Kalau saya nak pergi jumpa terus, mungkin orang tak terima saya. Jadi saya minta tolong YPU aturkan temu janji contohnya saya nak jumpa pihak Pertanian Negeri Terengganu. Jadi pihak YPU buat surat dan Jabatan Pertanian bagi peluang kepada saya untuk berjumpa. Ini semua hasil bantuan dari pihak YPU. YPU sebagai orang tengah" (P9)

Peluang-peluang perniagaan adalah seperti tender, geran, tapak ekspo keusahawanan, pembekal dan pasaran. Kesemua maklumat berkenaan peluang perniagaan ini dikongsi dalam kalangan rakan jaringan perniagaan, seminar keusahawanan dan semasa mesyuarat dalam persatuan. Selain berkongsi maklumat berkenaan peluang-peluang perniagaan, informan turut dibantu oleh agensi kerajaan seperti YPU yang bertindak sebagai perantara dalam membantu mendapatkan peluang-peluang perniagaan.

\section{Penilaian, Nasihat Dan Maklum Balas}

\section{Memperoleh Idea Perniagaan}

Informan dalam kajian ini memperoleh idea perniagaan dalam bentuk cadangan bagi tujuan penambahbaikan produk dan perkhidmatan. Berikut merupakan kenyataan informan:

"Setiap tahun pihak kesihatan membuat pemeriksaan di ladang saya dan memberikan cadangan untuk penambahbaikan di ladang saya untuk memastikan saya terus layak mendapat lesen penyembelihan untuk tahun2 seterusnya" (P20)

"Sebelum ini saya tidak tahu ketebalan plastik untuk rempah menjadikan produk saya tidak tahan lama. Jadi saya perlu bertanya pada pembekal plastik apa yang sesuai untuk produk saya. Pembekal juga memberitahu maklumat-maklumat tentang bahan yang digunakan oleh pesaing seperti Babas, Adabi dan lain-lain. Selain itu, pembekal juga memberitahu maklumat yang boleh digunakan untuk menambahkan lagi kualiti produk seperti produk untuk tahan lama" (P7)

Kenyataan di atas menjelaskan bahawa perkongsian maklumat daripada pembekal dan agensi kerajaan dapat memberikan pengetahuan baru kepada informan yang boleh digunakan untuk melakukan penambahbaikan kualiti produk dan perkhidmatan. Selain itu, hasil dari perkongsian maklumat daripada pembekal dan agensi kerajaan, informan dapat mengenal pasti kekurangan dan kelemahan terhadap produk, perkhidmatan dan fasiliti sedia ada bagi menjamin penghasilan produk yang berkualiti tinggi dan selamat.

\section{Mengetahui Cita Rasa Pelanggan}

Hubungan baik antara usahawan dan pelanggan membantu informan mengenal pasti cita rasa pelanggan dalam penghasilan produk dan perkhidmatan. Hasil dari kajian ini mendapati bahawa maklum balas yang diberikan daripada pelanggan berkenaan keinginan dan kehendak pelanggan 
memberikan idea baru kepada informan dalam menjalankan aktiviti perniagaan. Berikut adalah merupakan kenyataan informan tentang perkara tersebut:

"Sekarang saya baru terlibat dalam urusan jualan secara atas talian sebab mendapat banyak permintaan dari pelanggan yang ingin membeli secara atas talian" (P6)

"Mendapat maklum balas dari pelanggan berkenaan produk. Contoh pelanggan tidak tahu berapa berat bahan mentah yang diperlukan untuk satu paket rempah. Sebelum ini saya tidak meletak maklumat berkenaan. Setelah pelanggan selalu tanya berkenaan hal ini, saya telah membuat penambahbaikan bungkusan produk saya untuk memudahkan pelanggan" (P7)

Kenyataan di atas menjelaskan bahawa maklum balas dan keinginan pelanggan memberikan idea baru kepada informan dalam melakukan penambahbaikan produk dan perkhidmatan. Produk yang berkualiti dan perkhidmatan yang baik adalah penting dalam perniagaan supaya dapat menarik hati pelanggan untuk membeli. Maklum balas daripada pelanggan membantu informan mengetahui produk dan perkhidmatan yang bermasalah yang boleh menjelaskan kepuasan pelanggan. Hasil dari maklum balas ini membantu informan melakukan penambahbaikan kualiti produk dan perkhidmatan.

\section{Mengelak Dari Risiko Perniagaan}

Usahawan membina hubungan baik bersama pelanggan adalah bagi tujuan untuk menjual produk dan perkhidmatan. Selain itu, membina hubungan baik dengan pelanggan turut memberikan kelebihan kepada informan seperti mendapat pertolongan daripada pelanggan. Hasil kajian ini mendapati bahawa informan mendapat pertolongan daripada pelanggan. Berikut adalah merupakan kenyataan informan tentang perkara tersebut:

"Untuk mendapatkan perkhidmatan bantuan di luar negara, saya memilih untuk menggunakan agen yang berasal dari Malaysia yang tinggal di luar negara. Bagi tujuan untuk elak kena ditipu oleh orang luar" (P4)

Kenyataan di atas menjelaskan bahawa hasil hubungan baik antara informan dengan pelanggan, informan dapat mengelakkan dari sebarang risiko dalam perniagaan seperti penipuan yang boleh menyebabkan kerugian pada perniagaan. Ini membantu informan mendapatkan informasi dengan cepat dan tepat.

\section{Membincang dan Menyelesaikan Masalah}

\section{Menyelesaikan Masalah Perniagaan}

Salah satu pihak yang menjadi rujukan usahawan untuk menyelesaikan masalah adalah dengan merujuk kepada pihak kerajaan. Berikut adalah kenyataan informan tentang perkara tersebut:

"Jika saya menghadapi masalah dan memerlukan khidmat agensi kerajaan, saya akan ke agensi tersebut untuk membuat permohonan dan mereka akan datang mengenal pasti punca masalah dan mencadangkan jalan penyelesaian” (P4)

"Aktiviti persatuan kebiasaannya kami akan berbincang tentang masalah yang dihadapi dan mencari jalan penyelesaian. Persatuan berguna apabila perniagaan kita mengalami masalah. Kita menggunakan persatuan ini bagi tujuan untuk menyelesaikan masalah perniagaan kita" (P8)

Kenyataan di atas menjelaskan bahawa pihak kerajaan dan persatuan merupakan sumber rujukan bagi usahawan dalam membincang dan mencari jalan penyelesaian masalah perniagaan. Cadangan dari pihak kerajaan dan persatuan mampu menyelesaikan masalah yang dihadapi. Ini menjelaskan bahawa 
wujud keyakinan informan terhadap pihak kerajaan dan persatuan dalam membantu menyelesaikan masalah yang dihadapi.

\section{Perbincangan}

Secara keseluruhannya, dapatan kajian yang diperoleh melalui temu bual mendalam, maka model kelestarian perniagaan usahawan kecil dan sederhana Melayu dibina seperti Rajah 1 di bawah. Hasil kajian membuktikan bahawa jaringan sosial memainkan peranan yang penting dalam kelestarian perniagaan usahawan Melayu di Kuala Terengganu. Proses pembentukan nilai jaringan diasaskan pada hubungan bersama aktor jaringan primer dan aktor jaringan sekunder. Kekuatan aktor jaringan sosial melalui aktor jaringan primer dan aktor jaringan sekunder membantu usahawan Melayu memperoleh manfaat dari fungsi jaringan sosial melalui aktiviti jaringan sosial. Melalui aktiviti jaringan sosial, pertukaran nilai jaringan berlaku bagi mendapatkan sumber material dan bukan material yang dimiliki oleh aktor jaringan sosial. Setiap aktor jaringan sosial memiliki peranan dan nilai jaringan yang berbeza tetapi berkongsi matlamat yang sama iaitu memberikan nilai yang dapat dimanfaatkan oleh usahawan dalam menguruskan perniagaan. Aktor jaringan primer dibina pada asas hubungan yang rapat dan saling mempercayai, manakala aktor jaringan sekunder dibina pada asas hubungan perniagaan Granovetter (1973). Kedua-dua jenis aktor ini memainkan peranan yang berbeza, menghasilkan nilai jaringan yang berbeza, saling melengkapi dan saling diperlukan dalam membina sebuah perniagaan yang lestari. Ini selari dengan matlamat model kelestarian perniagaan yang mana mengoptimumkan nilai dan manfaat dari aspek ekonomi, sosial dan persekitaran (Geissdoerfer et al., 2020).

Jaringan primer dan jaringan sekunder menghasilkan nilai tangible dan nilai intangible seperti yang dijelaskan oleh Allee $(2008,2009)$. Kedua-dua nilai jaringan (tangible dan intangible) memainkan peranan penting terhadap kelangsungan perniagaan usahawan Melayu. Justeru, bagi membina nilai jaringan, perlu bagi usahawan menilai tahap keperluan dan nilai yang dimiliki oleh setiap aktor jaringan dan memilih aktor jaringan yang mampu memberikan nilai ekonomi dan sosial yang mana ini merupakan strategi dalam pemilihan aktor jaringan perniagaan (Allee, 2008). Oleh itu, pemilihan aktor jaringan sosial yang dapat memberikan nilai yang bermanfaat kepada perniagaan adalah penting dan merupakan asas dalam membina sebuah model kelestarian perniagaan yang berjaya. Model kelestarian perniagaan memerlukan nilai jaringan dari tingkah laku dan tindakan yang sistematik melalui peranan dan tanggungjawab daripada aktor jaringan (Evans et al., 2017). Nilai jaringan melibatkan perbezaan peranan pada setiap aktor dan keperluan organisasi yang berbeza, yang mana setiap aktor memberikan sumbangan dalam bentuk cadangan atau pandangan yang membentuk sebuah nilai yang bermanfaat kepada ahli dalam sesebuah jaringan (Den Ouden, 2012).

\section{Kesimpulan}

Penemuan utama kajian mendapati model kelestarian perniagaan dibentuk dari aktiviti pertukaran nilai bersama aktor jaringan sosial iaitu aktor jaringan primer dan aktor jaringan sekunder. Proses sosial yang tertanam dalam aktiviti jaringan sosial yang disertai oleh usahawan Melayu bersama aktor jaringan sosial menghasilkan sebuah perniagaan yang lestari yang bermatlamatkan nilai ekonomi, sosial dan persekitaran yang membentuk sebuah model kelestarian perniagaan seperti yang telah dibincangkan oleh Geissdoerfer et al. (2020). Proses sosial dalam kajian ini dapat diterjemahkan melalui bagaimana proses interaksi sosial bersama aktor jaringan sosial membantu usahawan Melayu memperoleh sumber yang bernilai yang memberikan impak atau hasil kepada kelangsungan sesebuah perniagaan. Ini sekali gus menjelaskan bahawa fungsi jaringan sosial adalah sebagai alat yang digunakan oleh usahawan bagi mencapai kelestarian perniagaan. 


\section{Rujukan}

Agbim, K.C. (2019). Social Networking and the Family Business Performance: A Conceptual Consideration. Journal of Entrepreneurship, Management and Innovation, 15(1): 83-122.

Allee, V. (2008). Value Network Analysis and value conversion of tangible and intangible assets. Journal of Intellectual Capital, 9(1): 5-24.

Allee, V. (2009). Value-creating networks: Organizational issues and challenges. The Learning Organization, 16(6): 427-442.

Bansal, S., Garg, I. \& Sharma, G.D. (2019). Social entrepreneurship as a path for social change and driver of sustainable development: A systematic review and research agenda. Sustainability (Switzerland), 11(1091): 1-28.

Boons, F. \& Lüdeke-Freund, F. (2013). Business models for sustainable innovation: State-of-the-art and steps towards a research agenda. Journal of Cleaner Production, 45: 9-19.

Chesbrough, H. \& Rosenbloom, R.S. (2002). The role of the business model in capturing value from innovation: evidence from Xerox Corporation's technology spin-off companies. Industrial and Corporate Change, 11(3): 529-555.

Clarkson, M.E. (1995). A Stakeholder Framework for Analyzing and Evaluating Corporate Social Performance. Academy of Management Review, 20(1): 92-117.

Doganova, L. \& Eyquem-Renault, M. (2009). What do business models do?. Innovation devices in technology entrepreneurship. Research Policy, 38(10): 1559-1570.

Evans, S., Vladimirova, D., Holgado, M., Fossen, K. Van, Yang, M., Silva, E.A. \& Barlow, C.Y. (2017). Business Model Innovation for Sustainability: Towards a Unified Perspective for Creation of Sustainable Business Models. Business Strategy and The Environment, 26(5): 597608.

Freeman, R.E. (2010). Managing for stakeholders: Trade-offs or value creation. Journal of Business Ethics, 96(1): 7-9.

Geissdoerfer, M., Pieroni, M.P.P., Pigosso, D.C.A. \& Soufani, K. (2020). Circular business models: A review. Journal of Cleaner Production, 277(123741): 1-17.

Geissdoerfer, M., Vladimirova, D. \& Evans, S. (2018). Sustainable business model innovation: A review. Journal of Cleaner Production, 198: 401-416.

Granovetter, M.S. (1973). The Strength of Weak Ties. The American Journal of Sociology, 78(6): $1360-1380$.

Greco, A. \& Jong, G. De. (2017). Sustainable Entrepreneurship : Definitions, Themes and Research Gaps. Campus Fryslân, 6(17): 1-36.

Gummerus, J. (2013). Value creation processes and value outcomes in marketing theory: Strangers or siblings? Marketing Theory, 13(1): 19-46.

Holm, D.B., Eriksson, K. \& Johanson, J. (1999). Creating value through mutual commitment to business network relationships. Strategic Management Journal, 20: 467-486.

Jack, S.L. (2005). The role, use and activation of strong and weak network ties: A qualitative analysis. Journal of Management Studies, 42(6): 1233-1250.

Klyver, K., Honig, B. \& Steffens, P. (2018). Social support timing and persistence in nascent entrepreneurship: exploring when instrumental and emotional support is most effective. Small Business Economics, 51(3): 709-734.

Lepak, D.P., Smith, K.G. \& Taylor, M.S. (2007). Value creation and value capture: A multilevel perspective. Academy of Management Review, 32(1): 180-194.

Lüdeke-Freund, F. \& Dembek, K. (2017). Sustainable business model research and practice: Emerging field or passing fancy? Journal of Cleaner Production, 168: 1668-1678.

Lux, S., Lamont, B.T., Ellis, K.M., Ferris, G.R. \& Muchira, J. (2016). Developing and Utilizing Efficient Ties in Entrepreneurial Networks in Africa. Africa Journal of Management, 2(1): 73-92.

Nosratabadi, S., Mosavi, A., Shamshirband, S., Zavadskas, E.K., Rakotonirainy, A. \& Chau, K. (2019). Sustainable Business Models : A Review. Sustainability, 11(1663): 1-30.

Den Ouden, E. (2012). Innovation Design: Creating Value for People, Organizations and Society. Springer: London.

Schaltegger, S., Hansen, E.G. \& Lüdeke-freund, F. (2016). Business Models for Sustainability: Origins , Present Research, and Future Avenues. Organization and Environment, 29(1): 3-10.

Syllick, T. \& Hockerts, K. (2002). Beyond the business case for corporate sustainability. Business 
Strategy and The Environment, 11: 130-141.

Teece, D.J. (2010). Business models, business strategy and innovation. Long Range Planning. 43(2): $172-194$.

Tsai, W. \& Ghoshal, S. (1998). Social capital and value creation: The role of intrafirm networks. Academy of Management Journal, 41(4): 464-476.

Walter, A., Ritter, T. \& Gemünden, H.G. (2001). Value Creation in Buyer-Seller Relationships. Industrial Marketing Management, 30(4): 365-377.

Zott, C. \& Amit, R. (2010). Business model design: An activity system perspective. Long Range Planning, 43(2): 216-226.

Zott, C., Amit, R. \& Massa, L. (2011). The business model: Recent developments and future research. Journal of Management, 37(4): 1019-1042. 